\title{
Forecast Indicators and Priorities of the Tourism Industry: A Study of Akmola Region, Kazakhstan
}

\author{
Zhanarys Raimbekov
}

Doctor of Economics, Professor, Department of Economics, L.N.Gumilev Eurasian National University Postal address: 2 Satpaev street, Astana, Kazakhstan 010010; Email: zh_raimbekov@mail.ru

Bakyt Syzdykbayeva

Doctor of Economics, Professor, Department of Tourism, L.N.Gumilev Eurasian National University Postal address: 2 Satpaev street, Astana, Kazakhstan 010010; Email: syzdykbaeva_bu@enu.kz

\section{Nurgul Esmagulova}

Candidate of Economic Sciences, Department of Economics, L.N.Gumilev Eurasian National University Postal address: 2 Satpaev street, Astana, Kazakhstan 010010 ; Email: esmagulova_nd@enu.kz

\section{Assel Baimbetova}

Candidate of Economic Sciences, Department of Tourism, L.N.Gumilev Eurasian National University Postal address: 2 Satpaev street, Astana, Kazakhstan 010010; Email: asel_baymbetova@mail.ru

\section{Bibikhazhar Salimova}

Candidate of Economic Sciences, Department of Tourism, L.N.Gumilev Eurasian National University Postal address: 2 Satpaev street, Astana, Kazakhstan 010010; Email: bibi641@mail.ru

\author{
Doi:10.5901/mjss.2015.v6n6p386
}

\begin{abstract}
This paper provides an analysis of tourism development in the Akmola region of Kazakhstan, as one of regional segments of the tourism industry within the domestic tourist market. This study aims to identify those main factors that restrict a process of the formation of regional economy, including the tourism industry. Despite the positive socio-economic impact of tourism on the economy, its contribution to the gross domestic product is very low and equals to about $1.0 \%$ in 2013. Tourism in Akmola region has great potential for development and could have a positive impact on the socio-economic development of the region. Akmola has considerable natural resources, occupies territory extremely favorable for development of tourist business. Thus, priorities of tourism industry development at the regional level were assessed. Forecast indicators of tourism development and its future directions were identified.
\end{abstract}

Keywords: tourism forecasting, tourism development, tourism industry, infrastructure of tourism industry, accommodation and food services, Kazakhstan.

\section{Introduction}

Tourism is a fast growing sector of the global economy. An analysis of its dynamic has been delivered by many authors such as Brymer (2001), Cooper (1993), Medlik (2000), Walker (2008), Kvartalniy (2003), Birzhakov (2002) and others.

However, in these studies there were no solutions on how to develop the regional markets of tourism services. Moreover, the above referenced studies are not adapted to the Kazakhstan market and rather focused strictly on the national markets of countries analyzed. In Kazakhstan, this field of study is more or less developed in several papers published by Nikitinsky (2008), Yulchieva (2004), Duysen (2010). The absence of comprehensive studies on the development of tourism, particularly at the regional scale, is the actuality of the study.

\section{Analysis of Main Problems and Factors}

The current state of the tourism industry in Kazakhstan is characterized by low level of resource bases and a significant 
mismatch between level, quality and structure of services provided to the population (Yulchieva, 2004).

In recent years, the major negative factors which contributed to the deterioration of the tourism service market include the falling of real incomes of the population, declining in domestic tourism traffic, reduced investment attractiveness of the tourism industry, lack of effective public policy in this field (Concept of development of the tourism industry of the Republic of Kazakhstan until 2020, 2014).

Today, almost all the existing forms of tourism are developing in Kazakhstan. In order to develop the tourism industry, cluster priority areas have been identified at the national level. Among them include business, environmental, cultural, educational, and extreme forms of tourism (Concept of development of the tourism industry of the Republic of Kazakhstan until 2020, 2014). Throughout the country, the largest number of tourists is served in the cities of Almaty and Astana, East Kazakhstan, Karaganda, Almaty, Atyrau and Akmola regions. In general, the reasons to travel to these regions are business and professional activity, recreation and leisure, shopping tours.

However, the resource base of tourism facilities, including hotels, boarding houses, as well as recreation and health resort facilities is highly deteriorated morally and physically. In addition, we can list a number of issues that limits the development of Kazakhstan as a tourism center in Central Asia: 1) insufficient development of the tourism and transport infrastructure; 2) low level of service and inaccessibility of historical sites on the Kazakh segment of the Great Silk Road; 3) low level of training, retraining and skills development and a lack of analytical and research base of tourism; 4) poor quality of services; 5) lack of attractiveness of Kazakhstan as a touristic destination.

The aim of the study is to forecast and prioritize the development of the tourism industry as an example of Akmola region of Kazakhstan.

\section{Literature Review}

Many less developed countries consider tourism as a quick way to make a profit and thus become a competitor, for example, agriculture, with its traditional mono- cultures. Hall (1995) argues that the main reason why governments, particularly in developing countries, paying attention to the development of tourism - attracting more investments that will contribute to the rapid economic development. Since these countries are usually poor and heavily in debt, and don't have experience in the tourism industry, the tourism infrastructure is heavily dependent on foreign investment (Mowforth \& Munt, 1998).

However, the development requires huge amounts of capital and foreign exchange proceeds or credits that less developed countries are unlikely to possess. Therefore, their government turned to tourism as a quick way of income needed for industrialization.

Kazakhstan for more than 20 years, due to the sale of raw materials (oil, gas, metal, grain, etc. ) has sufficient foreign exchange revenues (foreign exchange reserves of the National Bank and the National Fund assets made in March 2014. 99.3 billion U.S. dollars) which is used for the development of other economic sectors, including tourism.

Tourism is often seen as an important engine of economic growth and development of countries (Brida \& Risso, 2009; Tang \& Tan, 2013), thus increasing the economic welfare of the local population. This view is justified in the allocation of public resources to attract more visitors. However, in Kazakhstan's experience, despite the allocated public spending on tourism, improvement of the economic well-being through tourism is very low.

Extremely important is the existing relationship between economic growth and the development of tourism in developing countries (Song, Dwyer, Li, \& Cao, 2012). Although this topic is deeply researched, we agree with the authors that the 'Dutch disease' question is still a problem. Kazakhstan's economic growth over the last 5 years (2009 to 2013 ) was $6.5 \%$, but this does not lead to the rapid development of tourism, which is the average growth over the last five years is about $6 \%$.

Studies show (Antigua and Barbuda Tourism Development Program, 2003) that short-term and long-term strategic planning of tourism products in developing countries is often associated with such indicators as unemployment, inflation, currency restrictions and more.

Therefore, the economic impacts of tourism are an important factor in the state, regional, community planning and economic development.

\section{The Object of the Study}

The object of the study is Akmola region of Kazakhstan. The area of Akmola is equal to $146200 \mathrm{sq} \mathrm{km}$ or 5.4 per cent of a country's territory. Population is 735600 people (April, 2014), of which 46.9 per cent live in urban area, and 53.0 per cent in rural. 
The region is located in the north of the central part of Republic of Kazakhstan. The region has considerable economic potential and natural resources.

The region occupies territory extremely favorable for development of tourist business. Great possibilities have many areas of the region for internal tourism development. There is a developed network of rest houses, sanatoria, tourist bases, dispensaries, boarding houses etc.

Shuchinsk-Burabai resort zone is the resort place with fine natural-climatic conditions rich with medical-recreational resources and historical and cultural fund, favorable geographical arrangement in the center of Republic, affinity to Astana, the capital of RK.

There are national state parks 'Burabai', 'Kokshetau', and also the Korgalzhynsky reserve of the international value, one of the most unique places on a Eurasian continent.

Many areas of the region have great opportunities for the development of domestic tourism. There is a developed network of rest houses, sanatoria, tourist bases, dispensaries, boarding houses, and so on.

In order to attract foreign capital to further development of the resort area, a lot of attention is paid to the development of infrastructure.

The touristic potential of Akmola region makes it possible to provide rest to a great deal of tourists, both in summer and winter seasons.

There are total 2,200 rivers and 552 lakes in Akmola region. In general, Akmola has the opportunity to develop the following travel products: MICE-tourism, cultural and historical tourism, active and adventure tourism, boating on the lakes, rural tourism, social tourism, youth tourism, and farm tourism.

Despite its uniqueness, tourism of Akmola is not competitive enough and is losing to its foreign analogs on availability, service level and price of tourism services.

The purpose of research was to forecast the indicators and priorities of tourism industry development of Akmola, Kazakhstan. In order to reach the goal the following tasks have been solved: 1) an analysis of the current state of tourism development in Kazakhstan, and particularly in Akmola region; 2) provide a forecast for the main economic indicators of tourism and its development prospects.

\section{Methodology}

The study applied the methods of economic and statistical analysis. Its practical orientation required a marketing analysis of the industry, based on statistical data of the Agency of the Republic of Kazakhstan on Statistics, as well as a conducting a questionnaire survey of experts in Akmola region. Among the experts were respectively the heads of government agencies and tourism enterprises. A total of 50 people were surveyed. To forecast the performance of the tourism industry, the regression analysis is used.

\subsection{Regression model of assessment development prospects}

Assessment of the development prospects requires an evidence-based planning and forecasting of major economic indicators of tourist activities.

For the development prospects determination was held regression models construction, based on regression equations connecting the values of endogenous (output, dependent) and exogenous (input, independent) variables.

Generally, univariate regression model can be represented as:

$$
Y_{i}=f\left(x_{i}, A\right), \quad \mathrm{i}=1, \ldots, n
$$

where:

$\mathrm{y}_{\mathrm{i}}$ - simulated target meaning of in $\mathrm{i}$ - period;

$x_{i}$ - value of the factor in the $\mathrm{i}$ - period;

A - constant coefficients (model parameters);

$\mathrm{n}$ - number of periods over which the data are considered.

Regression model parameters are found by minimizing the sum of squared deviations:

$$
S=\sum_{i}\left(Y_{i}-f\left(x_{i}, A\right)\right)^{2} \rightarrow \min
$$

An important point in the construction of a regression function selection was $f$, specifying the particular form of communication. In the selection of the most appropriate forms of communication was resorted to the joint application of methods using both empirical and logical approaches. 
The adequacy of model was evaluated by Fisher's and Student's criteria. The tightness of connection indicator with the studied factors was determined by well-known correlation coefficient.

Test the significance of regression model was performed using Fisher's F-test (Granberg A.G, 1990).

\section{Main Results}

In Akmola, Kazakhstan, the main suppliers of tourism services in 2013 were the tourist organizations, represented by 189 travel agencies (total 3426 in Kazakhstan) and 31 individual entrepreneurs who have a license for undertaking a tourism activity. The greatest number of active travel companies and hotels were in the city of Almaty (1037), East Kazakhstan region (322), Karaganda region (300), Akmola region (189), and the city of Astana (405) (Smailov A, 2014).

According to the Agency of the Republic of Kazakhstan on Statistics in 2013, the tourism industry provided 67.8 thousand jobs in Kazakhstan, which is on 15.45 more than in 2012.

Hotels in Kazakhstan characterized by a low and decreasing occupancy rates (35\% in 2005, 25.3\% in 2013, comparing to the global average occupancy rate of 55-60\%), the growth of costs on the obsolete physical infrastructure and low margins (about 15\% compared to the global average level of 25.6\%). There are 117 three-, four-and five-star hotels; other hotels are identified as other forms of hotels.

Attractiveness of the region to visit is determined by the presence of resource and tourism potential. Akmola region has great opportunities for the development of both domestic and inbound tourism. With the presence of the main tourist resources, almost all types of tourism can be developed in these areas. The analysis showed that the hospitality industry in the region is represented by a set of enterprises and organizations of various departmental affiliations, with the participation of Kazakhstani and foreign capital.

The number of enterprises engaged in the tourist sector over the period from 2007 to 2012 increased from 111 to 189 units. The number of tourists served in the Akmola region in 2012 was 259668 people (10.0\% more than in 2011).

The number of foreign citizens who have entered the territory of the region increased from 2965 to 3616 people, tourists who left the territory also increased from 1485 to 5429 people for the period of 2007 to 2012.

Statistical data demonstrates that the trend of increasing the number of hotels and hotel room capacity remains. The growth of these indicators in 2012 to the level of 2007 was 3 times. Hotel occupancy rate was between 16.1-21.7\%. Analysis of the accommodation domestic market by class rating indicates the predominance of low-level categorized facilities. 3-5 star hotels $(17,2 \%)$ and hotels without categories $(43,2 \%)$ dominate in Kazakhstan on average.

One should note that hotels constructed with foreign participation primarily designed to serve business tourists have allowed decreasing the deficit of high class hotels. The cost of accommodation in these hotels is comparable to the cost of accommodation in major world capitals. Despite this, the occupancy rates and average prices in the upper price segment continue to increase. A significant excess of accommodation services demand over their supply is typical only for the cities of Astana and Almaty.

Low percentage of high comfort rooms in Kazakhstan and Akmola region shows that it is problematic to provide world standards for servicing foreign tourists. Under these circumstances, the quality of accommodation services focused on the vast majority of Kazakh consumers. Number of rooms for the period from 2007 to 2012 increased from 951 units up to 2886 units, the number of bed-days provided increased by 1.86 times (from 106806 to 199383), the average cost per bed-days decreased from 32.2 USD per day to 18.5 USD (Table 1). The total number of employees increased by 2.27 times.

Table 1. Basic indicators of hotels and other accommodation facilities in Akmola region

\begin{tabular}{|l|c|c|c|c|c|c|c|}
\hline & 2007 & 2008 & 2009 & 2010 & 2011 & 2012 & $\begin{array}{c}2012 \text { / } 2007 \\
\text { change in \% }\end{array}$ \\
\hline Number of rooms in total & 951 & 1083 & 1075 & 1308 & 2696 & 2886 & 303,3 \\
\hline Including luxury rooms & 279 & 342 & 361 & 416 & 668 & 818 & 293,2 \\
\hline Occupancy rate (\%) & 16,1 & 15,1 & 12,6 & 13,9 & 23,3 & 21,7 & 134,8 \\
\hline The average cost per bed-day, in USD & 32,2 & 36,4 & 28,4 & 28,8 & 19,6 & 18,5 & 57,5 \\
\hline The total number of employees during the reporting period & 736 & 797 & 939 & 932 & 1584 & 1674 & 227,4 \\
\hline $\begin{array}{l}\text { Note: Compiled according to the Department of Statistics of Akmola region } \\
\text { Exchange rate 1 USD }=182,5 \text { tenge }\end{array}$
\end{tabular}

Hotels with a minimum number of services make up a large part of the Akmola region sector and are in demand more 
from domestic citizens.

Solution to the shortage of accommodation in the near future would be to create a network of small hotels due to changes in accommodation facilities of buildings of historic and modern buildings.

Analysis of the dynamics of the structure and volume of the investments in the hospitality industry in the Akmola region indicates that investment growth is achieved through increased investment by private investors, mainly hoteliers, using its own funds and bank loans (Table 2).

Table 2. Dynamics of investments in the hospitality industry in the Akmola region

\begin{tabular}{|l|c|c|c|c|c|}
\hline & 2007 & 2010 & 2011 & 2012 & Growth in 2012 compared to 2007 in \% \\
\hline Fixed asset investment in region (millions of KZT), of which: & 103070 & 106864 & 122794 & 143782 & 139,4 \\
\hline - state & 30921,0 & 32059,2 & 42977,7 & 59799 & 193,3 \\
\hline - private & 72149 & 74804,8 & 79816,3 & 76924 & 106,7 \\
\hline - foreign & 1768 & 5866 & 7532 & 7059 & 399,2 \\
\hline Fixed asset investment by area (millions of KZT) & & & & & 154,2 \\
\hline -accommodation services & 1472 & 1867 & 997 & 2270 & 73,2 \\
\hline -arts, entertainment, and recreation & 5679 & 1415 & 2668 & 4158 & \\
\hline Note: According to the Statistics Agency. www.akmola.stat.kz
\end{tabular}

Development of the region depends not only on the presence of natural resources, but also on their level of availability. In Akmola region most of the costs are made up from transportation costs (49.3\% in 2012), 18.4\% on accommodation and living services, and $15.5 \%$ - on food expenses.

During the analysis of the tourism industry of Akmola region, using the method of ranking, the following priorities of the development of the entrepreneurial activity sphere were identified (Table 3).

Table 3. Ranking of priority areas of the hospitality industry organization in the Akmola region

\begin{tabular}{|l|c|c|}
\hline Direction & The average value of experts & Value \\
\hline 1. Communications & 3,7 & 4 \\
\hline 2. Infrastructure of tourism industry & 1,4 & 1 \\
\hline 3. The authorities' actions & 1,7 & 2 \\
\hline 4. Natural and cultural resources & 3,1 & 3 \\
\hline
\end{tabular}

value 1 - corresponds to the maximum specific weight, value 4 - minimum.

Estimates can be calculated by summing the values of four areas analyzed. These results show that the infrastructure of the tourism industry has a value of 1 , then in ascending order, the authorities' actions, resources and communications.

Overall, in order to further satisfactory operation of the current service complex, the development of infrastructure is required in the first place. Then, review of government policies in this field of the business and the use of communications tools to promote the services must be done which will allow the industry to develop comprehensively.

State of the tourism industry has a significant impact on a regional economic development in terms of promoting manufacture, trade, transport and communications. The development of the tourism industry in Kazakhstan is characterized by the entry of international hotels to the domestic market; intensive development of a network of small businesses and alternative forms of accommodation (apartments for rent); decrease in prices during crisis period; decline in the last 2-3 years of a number of tourists and hotels performance indicators; the highest demand for 4-star hotels and apartments rentals; introduction of new computer technologies.

There are no unified requirements and criteria to rate the hotels in Kazakhstan. For customers, lower prices and the possibility of residence itself are more important than the hotel's position in the ratings.

There is a reason to believe that foreign companies that actively develop their investment activity in the regions of the country will benefit in the future. International operators in the past_few years have revised their risk assessment policy in Kazakhstan and started moving from markets of Almaty and Astana to the regional centers. Assessment of the prospects of tourism development in Kazakhstan involves an analysis of the dynamics of entry and exit tourism flows. It should be noted that the unresolved problem of adequate statistics of tourism flows, in particular, registration of shuttle missions and illegal migration are responsible for the complexity of this analysis.

According to the official statistics, the total entry of foreign citizens to Kazakhstan in 2013 increased slightly: 10.1 million people against 9.06 million in 2012. Two-thirds of the total number of entries of foreigners falls in the former USSR 
citizens. The international tourism in Kazakhstan is progressing mainly with the orientation to outbound tourism. Internal tourism is still not developed, its share in GDP is low, but it has a high potential. Thus, the development of tourism as an important sector of the national economy requires a more efficient functioning of the hospitality industry. One should note that the tourism activity in Kazakhstan (by which we mean the activity of tour operators and travel agencies) provides no more than $10 \%$ of the total revenue of the industry, a much larger share of the total revenue is provided by the infrastructure of tourism facilities.

Tourism development in Akmola region is largely determined by the activity of tourism facilities. Most travel companies are characterized by a small number of employees. The attractiveness of the region is determined by availability of the resource base and recreational potential. Akmola region has a capacity to develop both domestic and foreign tourism (Development program of Akmola region, 2011). Potentially by the resource provision almost all types of tourism can be developed in the region. The analysis shows that the hospitality industry in the region is represented by a set of institutions of various form of ownership, with the participation of the local and foreign capital.

As it is clear from the analysis of the current state of tourism in Akmola region, tourism agencies in the region are not interested in investing their money in the development of regional tourism. It is more important for them to improve the quality of the tourism industry in recreational areas in Kazakhstan and foreign countries, where they target their customers. In our opinion, main objectives in the context of investment policy of the regional tourism hospitality industry in Kazakhstan are as follows:

- To stimulate investment projects of regional tourism facilities;

- To develop incentives for foreign investors and increase their participation;

- To attract both domestic and foreign banking capital investments;

- To provide assurance of a minimal risk of investment projects in the field of tourism;

- To increase the efficiency of public and private investments (to expand consumer properties of touristic products, to reduce construction time, to streamline pricing, etc.).

The effectiveness of the investment policy of the regional tourism industry can be achieved by:

- Sequential decentralization, i.e. development of investment activities directly in the regions within regional projects;

- Significant expansion of a joint (shared) state commercial financing of investment projects;

- Strengthening a role of credit, a gradual expansion of crediting in investment activity in tourism;

- Selection of regional tourism objects for government contract funding, on a basis of expertise and feasibility of projects. The main criteria of such selection should be the efficiency and return on investment;

- Expansion of the small business, regardless of industry and ownership.

Forecast of profit is closely related to the volume of service provision and the forecast of income level of population. Table 4 presents predictive models of the regression analysis of socio-economic factors of tourism services in Akmola region.

Table 4. Predictive models of regression analysis of the socio-economic factors of tourist services in the Akmola region

\begin{tabular}{|c|l|l|c|c|c|}
\hline \multirow{2}{*}{} & & & \multicolumn{3}{|c|}{ Equation characteristics } \\
\cline { 3 - 6 } & Factor & Model equation & $\begin{array}{c}\text { Mean- } \\
\text { Square } \\
\text { Deviation,Sy }\end{array}$ & $\begin{array}{c}\text { Correlation } \\
\text { Parameter, } \\
\mathrm{R}^{2}\end{array}$ & $\begin{array}{c}\text { Fisher } \\
\text { Coefficient, } \\
\mathrm{F}\end{array}$ \\
\hline 1 & $\begin{array}{l}\text { Travel businesses and travel agents revenue (thousand } \\
\text { KZT) }\end{array}$ & $\mathrm{Yt}=1437,1+3378,1 \mathrm{t}$ & 40726 & 0,97 & 217,7 \\
\hline 2 & Hotel services revenue (thousand KZT) & $\mathrm{Yt}=14359+7263,5 \mathrm{t}$ & 103494 & 0,94 & 83,1 \\
\hline 3 & Health resort institutions revenue (thousand KZT) & $\mathrm{Yt}=5038,6+1822 \mathrm{t}$ & 25659,5 & 0,94 & 85,8 \\
\hline 4 & Cultural-enlightenment institutions revenue (thousand KZT) & $\mathrm{Yt}=4576,4 \times \mathrm{EXP}(0,2651 \mathrm{t})$ & 46685,5 & 0,93 & 67,0 \\
\hline 5 & Population's nominal income (KZT) & $\mathrm{Yt}=18135,5+6012 \mathrm{t}$ & 11817,32 & 0,90 & 38,50 \\
\hline 6 & $\begin{array}{l}\text { Structure of population's consumption expenditure (paid } \\
\text { services), } \%\end{array}$ & $\mathrm{Yt}=25,1-0,08 \mathrm{t}$ & 0,408248 & 0,39 & 0,72 \\
\hline 8 & Investment in HoReCa (million KZT) & $\mathrm{Yt}=-12141,5+6364,2 \mathrm{t}$ & 14511,72 & 0,67 & 8,23 \\
\hline 9 & Tourism services (million KZT) & $\mathrm{Yt}=-1,23+7,97 \mathrm{t}$ & 15,28 & 0,95 & 79,40 \\
\hline 10 & Number of persons employed in tourism & $\mathrm{Yt}=414,9+108,5 \mathrm{t}$ & 209,44 & 0,93 & 62,60 \\
\hline
\end{tabular}

Based on the research results we can distinguish the following main trends of the tourism industry services market in Akmola region:

- Recovery of the market followed by improving of economic situation (capacity, scope of services, other 
characteristics);

- Growth points emergence generating innovative impulses;

- Dominance of non-categorized accommodation facilities in the tourism infrastructure; limited number of hotels able to provide with sufficient comfort; considerable moral and physical deterioration of existing facilities;

- Insufficient investments and undiversified structure of their sources;

- Limited range and insufficient quality of services provided;

- Lack of management and low professional level of human resources.

This determines the need to develop the tourism infrastructure considering the existing demand: tourist class hotels that provide relatively inexpensive, but high-quality services with a set of additional infrastructure for rehabilitation, recreation and business activities, modern small hotel, specialized accommodation facilities; to improve the professional level of the management; to stimulate investments in the tourism sector of the region.

The results of our research show that tourism activities have a positive impact on the level of incomes. Profit forecast values can be used for strategic planning of the tourism industry. The implementation of our recommendations could be used by the regional authorities as a clear strategic goal in the formation of the market of services of the tourism industry. The presented models implement econometric approaches to forecast process. Table 5 attempts to predict the number of qualitative and quantitative indicators of the development of the tourism industry in Akmola region.

These data can be used for strategic planning for the tourism industry, defining an alternative strategy for management decisions. Obtained results indicate that in the tourism industry in Akmola region a general upward trend takes place. The calculated data show a stable trend in these areas, which is important for the development of the tourism industry as a whole and its separate directions.

Table 5. Forecast on trend regression models of the tourism industry in Akmola region

\begin{tabular}{|l|c|c|c|c|}
\hline Factor & 2012 & 2013 & 2014 & 2015 \\
\hline Travel businesses and travel agents revenue (million KZT) & 28461,9 & 31840 & 35218,1 & 38596,2 \\
\hline Hotel services revenue (million KZT) & 72467 & 79730,5 & 86994 & 94257,5 \\
\hline Health resort institutions revenue (million KZT) & 19614,6 & 21436,6 & 23258,6 & 25080,6 \\
\hline Cultural-enlightenment institutions revenue (million KZT) & 38157,1 & 49740,2 & 64839,3 & 84522,1 \\
\hline Population's nominal income (KZT) & 66231,5 & 72243,5 & 78255,5 & 84267,5 \\
\hline Works and services provided in tourism (thousand KZT) & 1808914 & 17957154 & 2263794 & 2491234 \\
\hline Investment in HoReCa (million KZT) & 38772,1 & 45136,3 & 51500,5 & 57864,7 \\
\hline Tourism services (million KZT) & 62,53 & 70,5 & 78,47 & 86,44 \\
\hline Number of persons employed in tourism & 1282,9 & 1391,4 & 1499,9 & 1608,4 \\
\hline
\end{tabular}

\section{Discussion and Conclusion}

The results, obtained by correlation- regression method, indicate that the tourism industry has a general upward trend.

Forecast of tourism revenue indicates that an important contribution in tourism development in terms of profitability, is primarily the development of accommodation and catering services, then activities of travel agencies, and last are spa facilities.

These data demonstrate that in subsequent years accommodation and food services will be actively developed, which is important for the development of the hospitality industry with the development strategy involving public-private partnership.

An international experience analysis of countries at a similar stage of development shows that the development of tourism without the active state participation is impossible. As in all successful cases, (Spain - 1950, Mexico - 1970, Egypt, Dubai, Morocco, Malaysia and Turkey - 1980 -1990s, Russia and Abu Dhabi - 2000s.) it is exactly a state on the basis of the political will of senior management creates a unique priority for tourism in the regulatory sphere, the state plays an active investor role in new resort areas, finances a creation of engineering and transport infrastructure, engaged in advertising and promotion of the country as a tourist destination.

The measures, for example, such as an improvement and a reduction of the visa application process duration, facilitating the migration regime, will make Kazakhstan more attractive place to visit. This may include a cost reduction of airline tickets, the marketing strategy development and positioning the country as a tourist destination in the international tourism market, as now, the majority of foreign citizens are not aware of the Kazakhstan's tourism opportunities.

Creating new tourism projects will contribute to the development of various tourism-oriented proposals that meet 
the needs of different tourist categories.

It is impossible to create without appropriate investment, state support and public-private partnership, a competitive tourism industry for employment, steady growth of state and public revenue by increasing the volume of inbound and domestic tourism. For tourism development, investments are required in infrastructure and quality service.

Acceptable scenario, capable to provide a sustainable development and an achievement of strategic targets of tourism development for the coming years is to improve planning and forecasting. All efforts of Kazakh scientists and managers at all levels of management should be focused on developing tourism policy. Tourism infrastructure along with budgetary funds is likely to require significant private investment, including funds and holding companies, leading economic activity in a certain area. This can be achieved by establishing favorable conditions for business in the tourism industry.

The main problems limiting the development of tourism industry in the country in general and in its regions in particular can be summarized as the following: low quality and underdevelopment of the infrastructure, lack of information, lack of development strategy and market-oriented management. The above-mentioned problems can be solved by implementing of the set of activities aimed at promoting various types of tourism, improving the quality of the services provided, developing modern entertainment industry, IT penetration, promoting and advertising of the region as a tourism center. The strategy for the development of the tourism industry should be elaborated, and the activity of actors in this industry should be coordinated.

Acceptable scenario is able to ensure the sustainable development and the achievement of strategic goals of tourism for upcoming years, could be the improvement of planning and forecasting. This should be the priority of the state policy in tourism.

\section{References}

2010-2014 State Program of accelerated industrial and innovative development of the Republic of Kazakhstan. (2010, March 19). Decree of the President of the Republic of Kazakhstan. Retrieved from http://www.government.kz

Antigua and Barbuda Tourism Development Programme. (2003). Tourism's Economic Impacts Increasing the Contribution to Prosperity. [Online] Available: http://www.tourismantiguabarbuda.gov.ag/tourism_programs/pdf/planning_eis_study.pdf.

Birzhakov, M.B. (2002). Introduction to Tourism. Saint Petersburg: Nevski fond.

Brida, J. G., \& Risso, W. A. (2009). Tourism as a factor of long-run economic growth: an empirical analysis for Chile. European Journal of Tourism Research,

Brymer, R.A. (2001). Fundamentals of management in the hospitality industry. Kiev, Ukraine.

Concept of development of the tourism industry of the Republic of Kazakhstan until 2020. (2014, May 19) Resolution of the Government of the Republic of Kazakhstan. [Online] Available: http://www.government.kz

Cooper, C., Fletcher, J., Gilbert, D., \& Wanhill, S. (1993). Tourism: principles \& practice, Longman, Harlow, UK.

Duysen G.M. (2010) Recreational development of the regions of Kazakhstan in the conditions of entry into the world tourism: Theory, Strategy and Practice. Almaty, Kazakhstan.

Granberg, A.G. (Ed.). (1990). Statistical modeling and forecasting. Moscow: Finance and Statistics.

Hall, C.M. (1995). Tourism, Ecotourism and Protected Areas. Gland: IUCN Publication.

Kvartalniy V.A. (2003). Theory and practice of tourism. Moscow: Finance and Statistics.

Mowforth, M., \& Munt, I. (1998). Tourism and Sustainability. New Tourism in the Third World. London: Routledge.

Medlik, S., \& Ingram, H. (2000). Business of Hotels. Taylor \& Francis.

Nikitinsky, E.S. (2008). Silk Road cities forum - a new level of regional and international cooperation for the development of tourism in the ancient, historic track.

Smailov, A.A. (Ed.). (2014). Kazakhstan Tourism 2009-2013. Statistical compilation. [Online] Available: http://www.stat.kz/publishing/ 2014.pdf

Song, H., Dwyer, L., Li, G., \& Cao, Zh. (2012). Tourism economics research: a review and assessment. Annals of Tourism Research, Vol. 39 (3).

Tang, C.F., \& Tan, E.C. (2013). How stable is the tourism-led growth hypothesis in Malaysia? Evidence from disaggregated tourism markets. Tourism Management, 37, 52e57.

Yulchieva, G.N. (2004) The organization of the hotel industry in a globalized economy. Almaty: Classical.

Walker, J. (2008). Introduction to Hospitality (Trans.). Moscow: Unity. 